\title{
Enlightenment of International Comparative Study of Teacher Educators from the International Perspective
}

\author{
PI Xue-di
}

\begin{abstract}
(The University of Manchester, School of Environment, Education and Development)
\end{abstract}
Abstract: This paper conducts research on the inspiration of international comparison of teacher educators from the perspective of internationalization. Based on the background of the era of internationalization, it analyzes the differences of teacher educators in various aspects in various countries, mainly including the comparison of teacher educator education reforms and teacher educator training systems. The comparison of the content and methods of teacher educators' further education, comparison of the main measures to encourage teacher educators in other countries, etc., and the corresponding enlightenment have been drawn, which is of great significance to promote the internationalization of teacher educators.

Keywords: teacher educator, international comparison, internationalization, inspiration

\section{Introduction}

For the education of teacher educators, this is an educational concept extended from the perspective of lifelong education, and the corresponding training work is carried out from the professional perspective of teacher educators, which is mainly reflected in previous training, onboarding training, and These three aspects of on-the-job training are also pre-service and post-service education activities for teachers engaged in education. The content of teaching will be set according to the teacher's own situation, and the time of education is mainly reflected in regular and irregular. The ultimate purpose of carrying out teacher educator education activities is to strengthen the training of teachers, so that they can become a professional educator. The development of teacher educator education has largely determined the quality of teacher educators and the quality of education.

In the context of internationalization, the internationalization of education has also become the key to promoting teaching reform and achieving the development of comprehensive quality education, and is the main driving force for the development of education and culture in China. At the beginning of 2019, in the first educational outline for education modernization in China, "Chinese Education Modernization 2035", the Chinese government even more clearly pointed out that a new pattern of education opening up was opened. The promulgation of a series of national policy texts pointed out the direction of the international development of basic education in China, and demonstrated China's determination to follow the development trend of the world's basic education and integrate into the world's basic education system. Since the implementation of China's reform and opening up policy, our government has promulgated a series of national policies to promote the internationalization of education. Education internationalization focuses on the cultivation of teachers' international vision, clarifies the rules of international education, and strengthens teachers' response to international affairs, and enhances the competitiveness of international talents.

At present, the internationalization of China's basic education is developing rapidly. One-way learning in the early days of reform and opening up has borrowed from Western developed countries' educational experience and simple exchanges between teachers and students in the field of education. It has gradually moved to a stage of deep-level cooperation and innovation such as two-way exchanges of curriculum teaching and management. The international department (class) of public schools is the main form of practicing international education. In recent years, the number of international departments has been increasing, and it has gradually extended from the developed areas in the east and the coast to the west. Therefore, based on the background of internationalization, studying the international comparison of teacher educators is of great significance, and it has a good reference for the reform and development of teacher educators' education in China.

\section{Teacher educator}

"Teacher educator" as the name implies refers to the person who educates teachers. After the 1930s, along with the development of teacher educator education, the status of traditional teacher education has also been seriously affected, and teacher educator education has gradually become a universal concept of teacher education in the world. (P83), the title of teacher educator has gradually begun to attract the attention of academia. It is generally believed that teacher educators are at the core of the professional construction of teacher educators, which is crucial to the overall quality of the teacher educator team. Teacher educators are a very heterogeneous group, not only from different sources and backgrounds, but also from different working environment [1]. In some countries, teacher educators include only college teacher educators; in other countries, they include both educators and researchers, as well as elementary and middle school 
teacher educators related to continuing professional development (Fig. 1).

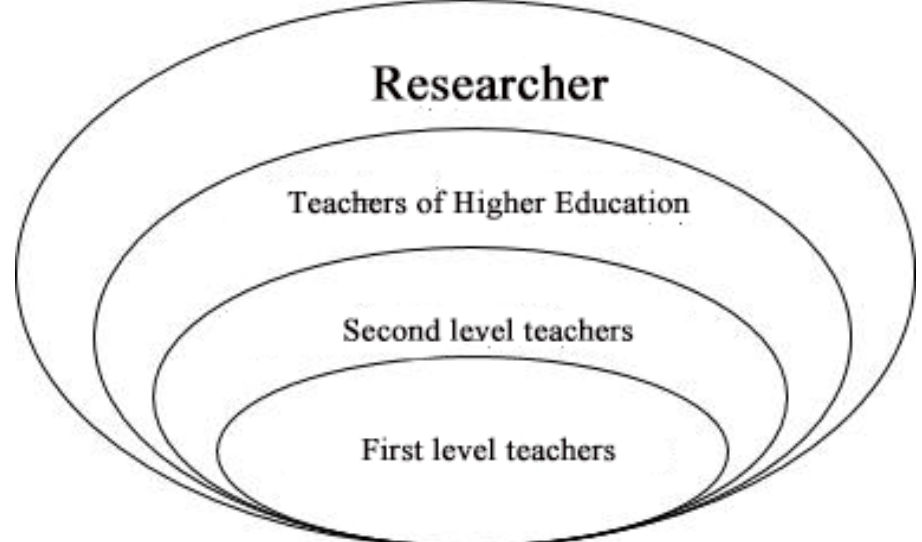

Fig.1 Sub-identities of teacher educators in higher education

\section{INIERNATIONALCOMPARITIVEOFTEACHER EDUCATORSFROMTHEINTERNATIONALPRESPECTIVE}

\subsection{Comparison of teacher educator education reforms}

For developed countries, the competition in the education system is mainly reflected in the competition of teachers, and the development of education is absolutely inseparable from a strong teacher team.

United States. Teacher educator education in the United States is divided into two important stages: one is the training of teacher educators in universities; the other is on-the-job training. The two are continuous. Even if the teacher educator has completed all the courses of the university, it cannot be said that he has become a mature teacher educator. In order to be a good teacher educator for life, we must learn the necessary knowledge and technology, the purpose is to strengthen the training of teacher educators, to achieve professional education, so as to provide a large number of outstanding teachers for the country. In 1994, President Clinton enacted two provisions on education reform in the Federal Education Act. Among them, it was proposed that we should focus on the education of teacher educators and strengthen the professional development of teacher educators, so as to strengthen the team of education educators, and also proposed that the United States should realize the professionalism of educators by the year 2000 . In the $21 \mathrm{st}$ century, all American teenagers must have the necessary knowledge and corresponding technology. Aiming at this goal, it is proposed to strengthen the professional training level of teacher educators, especially to learn computer technology[2].

Japan. In the 1990s, the Japanese government regarded improving the quality of teacher educators as the focus of Japanese education. And in order to further strengthen the quality level of teacher educators, the Ministry of Education and Culture has also divided the three aspects of teacher educators' training and education, which are mainly reflected in the three aspects of training, appointment and further education. In recent years, Japanese teacher educators have also paid great attention to these three contents, and have strengthened the quality training of teacher educators in the education system. After 2000, the Japanese Ministry of Education required future teacher educators to have the quality to cultivate students 'survivability, and to apply the teaching methods to specific teaching environments, improve students' psychological and emotional awareness, and use their own Quality level for student education. At the same time, it is also necessary to actively strengthen the level of interpersonal communication of students, to enable them to be familiar with the social environment, and to provide comprehensive education for students[3].

The "White Paper on Competitiveness" issued by the British Government in 1995 explicitly proposed the reform and innovation of the education system, and merged the Ministry of Education and Department of Employment and Vocational Training. The merged department is called the Ministry of Education and Employment. The work of this institution is to carry out educational activities and cultivate employment skills and literacy of talents[4].

Expenditures on education services reflect the comparative advantages of a country's education level and the world's education level. In order to compare the comparative advantages of China and Japan more directly, the data selected in this article are from $2006-2019$. 
Table1 Comparison of China-Japan Educational Services Export Units: USD 100 million

\begin{tabular}{cccc}
\hline years & Japan & China & $\begin{array}{c}\text { ratio } \\
\text { (Japan is better than } \\
\text { China) }\end{array}$ \\
\hline 2006 & 394.6 & 656.8 & 0.0265 \\
2007 & 427.9 & 775.7 & 0.0233 \\
2008 & 594.9 & 975.6 & 0.0224 \\
2009 & 703.1 & 1103 & 0.0248 \\
2010 & 925.3 & 1173.4 & 0.0262 \\
2011 & 1200 & 2930 & 0.0112 \\
2012 & 1536.9 & 3450 & 0.0107 \\
2013 & 1936.7 & 3700 & 0.0118 \\
2014 & 2358.9 & 4140 & 0.0121 \\
2015 & 2559.6 & 4538 & 0.0125 \\
2016 & 2837.8 & 4896 & 0.0131 \\
2017 & 3256.9 & 5235 & 0.0135 \\
2018 & 3365.4 & 5768 & 0.0132 \\
2019 & 3628.1 & 6132 & 0.0135 \\
\hline
\end{tabular}

According to the calculation results in the table above, it can be seen that China's expenditure on teacher education services has increased year by year, especially in the previous years. The competitiveness of China's international education services is gradually catching up, and the gap with Japan is gradually narrowing. However, judging by the absolute value of the index, there are still some other gaps in education services between China and Japan. China still needs a long time to catch up with Japan and gradually narrow the gap. China's education services still have a long way to go.

\subsection{Comparison of Teacher Educator Training System}

\subsubsection{Comparison of Contents and Methods of Teacher Educators}

In order to improve the quality of teaching, many developed countries have developed multi-style teacher training methods, which are mainly reflected in the two aspects of short-term education and long-term education. And informality, as a whole, through a variety of teaching activities to further improve the cultivation of teachers 'quality and strengthen teachers' technical level. Various countries in the world for on-the-job education training activities are mainly reflected in the two aspects of obtaining a degree qualification and strengthening the quality of teaching. A comparison of the training content and methods of teacher educators in Britain, France, and Germany is shown in Table 1:

Table 2 Comparison of training methods for teacher educators in Britain, France and Germany

\begin{tabular}{|c|c|c|}
\hline United Kingdom & France & Germany \\
\hline $\begin{array}{l}\text { To obtain a teacher educator } \\
\text { status and a bachelor's } \\
\text { degree from a teacher } \\
\text { educator; } \\
\text { Strengthen the training leve } \\
\text { of in-service teachers and } \\
\text { improve their degree. }\end{array}$ & $\begin{array}{l}\text { Elementary teacher educators: one semester of } \\
\text { long-term education and one and a half months of } \\
\text { r medium-term education; } \\
\text { Junior high school teacher educators: short-term } \\
\text { training for } 2-3 \text { days; } \\
\text { High school teacher educators: It takes a minimum } \\
1 \text { of } 2-10 \text { days to send to relevant companies for a one } \\
\text { and a half month study } \\
\text { Teacher educators in secondary vocations: One-year } \\
\text { corporate learning and } \\
3-15 \text { days of short-term training, etc. }\end{array}$ & $\begin{array}{l}\text { Further education } \\
\text { in state teacher } \\
\text { education; } \\
\text { Volunteer } \\
\text { participation in } \\
\text { e teaching seminars, } \\
\text { workshops, etc. } \\
\text { r organized by the } \\
\text { government }\end{array}$ \\
\hline
\end{tabular}

United Kingdom. Teacher education in the United Kingdom can be broadly divided into two types: one is to obtain a teacher educator status and obtain a bachelor's degree from a teacher educator; the other is to strengthen 
education and other teaching content. In addition, there are many ways for teachers and educators to further their studies, including voluntary participation in government-sponsored teaching seminars, workshops, and so on. Generally speaking, if teacher educators want to get a higher level of qualification, then they need to take a long vacation to go to university or college of education for further studies[6]; for the continuing education activities of teacher educators, it is mainly reflected in content In environmental education, peace education, technical education, etc.

China's teacher educator education market has changed due to changes in the statistical methods of the teacher educator education market in China. That is, the National Bureau of Statistics has issued a new standard for self-cultivation. In the new standard, the statistical method for the output value of China's teacher educator education market has occurred Very large changes, mainly due to changes in statistical methods. According to data from the National Bureau of Statistics, the market size of China's teacher educator training market in 2019 is 426.8 billion yuan, a year-on-year increase of $14 \%$. Compared to the speed of China's economic development, the development of the teacher educator training market still maintains a high speed growth of. Although China's teacher educator training market is developing at a faster pace, the level of development will still be relatively low. Compared with developed countries such as the United States and Japan, there is still a huge gap. This gap is not only reflected in the international scale. Compared with the gap, it also reflects the soft power of a country. By 2010-2019 for market size, China's education market of teacher educators, teacher educators training our market size of the market is increasing, the proportion is increasing too, the proportion steadily. The training activities here mainly focus on two aspects of teaching technology and teaching content. It also includes environmental education, information technology Table 3 The scale of teacher education in China

\begin{tabular}{ccccc}
\hline time & scale & growth rate & International & Proportion of international \\
\hline 2010 & 695.89 & & 28435 & $2.45 \%$ \\
2011 & 925.34 & $33 \%$ & 34525 & $2.68 \%$ \\
2012 & 1112.46 & $20 \%$ & 45781 & $2.43 \%$ \\
2013 & 1250 & $12 \%$ & 49898 & $2.5 \%$ \\
2014 & 1632 & $31 \%$ & 58786 & $2.78 \%$ \\
2015 & 2327 & $43 \%$ & 70735 & $3.29 \%$ \\
2016 & 2719 & $17 \%$ & 78159 & $3.48 \%$ \\
2017 & 3229 & $19 \%$ & 86046 & $3.75 \%$ \\
2018 & 3740 & $16 \%$ & 94032 & $3.89 \%$ \\
2019 & 4268 & $14 \%$ & 99569 & $3.52 \%$ \\
\hline
\end{tabular}

From the perspective of the scale and international proportion of the teacher educator training market, as time goes by, the domestic teacher education training market accounts for an increasing proportion, with the highest value-added and proportion in 2019. From this point of view, the teacher educator education market in our country is developing vigorously, and it will be further developed in the future. 
Table 4 US Education Service Market Competitive Advantage Index

\begin{tabular}{cccccc}
\hline years & $\begin{array}{c}\text { American } \\
\text { Education } \\
\text { Service } \\
\text { Quota }\end{array}$ & $\begin{array}{c}\text { U.S. Educational } \\
\text { Services Progress } \\
\text { Quota }\end{array}$ & $\begin{array}{c}\text { Difference(export } \\
\text {-Import value) }\end{array}$ & $\begin{array}{c}\text { Total(exports } \\
\text { +Import) }\end{array}$ & $\begin{array}{c}\text { AmericanTC } \\
\text { index }\end{array}$ \\
\hline 2006 & 17.41 & 14.7 & 2.71 & 32.11 & 0.084397 \\
2007 & 18.06 & 13.12 & 4.94 & 31.18 & 0.158435 \\
2008 & 21.88 & 19.6 & 2.28 & 41.48 & 0.054966 \\
2009 & 27.35 & 25.52 & 1.83 & 52.87 & 0.034613 \\
2010 & 30.7 & 28.77 & 1.93 & 59.47 & 0.032453 \\
2011 & 32.9 & 30.82 & 2.08 & 63.72 & 0.032643 \\
2012 & 36.8 & 32.67 & 4.13 & 69.47 & 0.05945 \\
2013 & 43.7 & 36.55 & 7.15 & 80.25 & 0.089097 \\
2014 & 50.1 & 34.28 & 15.82 & 84.38 & 0.187485 \\
2015 & 56.9 & 42.56 & 14.34 & 99.46 & 0.144179 \\
2016 & 64.2 & 51.67 & 12.53 & 115.87 & 0.108138 \\
2017 & 70.6 & 56.89 & 13.71 & 127.49 & 0.107538 \\
2018 & 75.96 & 58.79 & 17.17 & 134.75 & 0.127421 \\
2019 & 82.69 & 61.55 & 21.14 & 144.24 & 0.146561 \\
\hline
\end{tabular}

Table 5 Index of Competitive Advantage of China's Education Service Market

\begin{tabular}{cccccc}
\hline years & $\begin{array}{c}\text { China Education } \\
\text { Service } \\
\text { Market export } \\
\text { value }\end{array}$ & $\begin{array}{c}\text { China Education } \\
\text { Service } \\
\text { Market imports }\end{array}$ & $\begin{array}{c}\text { Balance(exports- } \\
\text { Import value) }\end{array}$ & $\begin{array}{c}\text { Total(exports } \\
\text { amount+import } \\
\text { amount) }\end{array}$ & China TC Index \\
\hline 2006 & 0.05 & 0.96 & -0.91 & 1.01 & -0.900990 \\
2007 & 0.08 & 0.7 & -0.62 & 0.78 & -0.794872 \\
2008 & 0.09 & 1.76 & -1.67 & 1.85 & -0.902703 \\
2009 & 0.13 & 1.54 & -1.41 & 1.67 & -0.844311 \\
2010 & 0.17 & 1.2 & -1.03 & 1.37 & -0.751825 \\
2011 & 0.21 & 1.54 & -1.33 & 1.75 & -0.760000 \\
2012 & 0.26 & 1.78 & -1.52 & 2.04 & -0.745098 \\
2013 & 0.34 & 2.15 & -1.81 & 2.49 & -0.726908 \\
2014 & 0.39 & 1.96 & -1.57 & 2.35 & -0.668085 \\
2015 & 0.42 & 2.23 & -1.81 & 2.65 & -0.683019 \\
2016 & 0.48 & 2.98 & -2.5 & 3.46 & -0.722543 \\
2017 & 0.53 & 2.57 & -2.04 & 3.1 & -0.658065 \\
2018 & 0.64 & 3.12 & -2.48 & 3.76 & -0.659574 \\
2019 & 0.75 & 3.97 & -3.22 & 4.72 & -0.682203 \\
\hline
\end{tabular}

Compared with this, China 's education service market has its own unique characteristics compared with a powerful country like the United States. With the gradual development of China's education services, it will gradually eat away at Japan 's share internationally. In the near future, China's education market will surely surpass the United States and become a world power in education.

\subsubsection{Comparison of major measures to} encourage teacher educators in other countries

Update teacher educator qualification. The United States government requires that all teacher educator certificates 
have a certain validity period, so it needs to be renewed after this validity period has expired, otherwise teacher educator qualifications will be lost. In addition, in terms of certificate renewal, comprehensive considerations need to be made from the perspective of professional development. Generally, certificate renewal is performed within a five-year period. If it is only to maintain the current qualification, you must participate in the study to obtain all the credits[7].

In order to encourage teacher educators to improve their own quality, various countries have formulated incentive measures to support the further development of teacher educators, the purpose of which is to improve the quality of teacher educators and thereby strengthen the development of education. Short-term teacher educators in the U.S. are free of charge, while in the UK they are waived for long-term studies.

All expenses will be borne by the Ministry of Education and Science, and corresponding subsidies will be paid to the advanced teachers. Teacher educators in Germany have a certain public holiday, and further education costs are borne by the school. Japan allows teachers and educators to pay for a master's degree, thereby increasing their degree[5].

Many countries have established the right of teacher educators to have paid leave for further studies. For example, the United States allows teachers who have been teaching for more than six years to take paid vacations for one year for further education. The UK spends seven years in this area, and teacher educators who work seven years enjoy the opportunity to take one year's paid vacation. In Germany, as long as you are a good teacher, you can apply for a paid vacation for one year at any time. Teacher educators in Russia can also apply for paid employment to pursue a doctorate[8].

\section{ENLIGHTENMENT OF INTERNATIONAL COMPARITIVESTUDY OFTEACHEREDUCATORS FROMTHE INTERNATIONAL PERSPECTIVE}

\subsection{Strictly control the threshold of "entry" for teacher educators}

At present, the entry requirements for teacher educators in different countries are not the same, but there is also uniformity that is high education and outstanding level of practice. In addition, the basic requirement for teacher educators abroad is to have a bachelor's degree or above, have working experience in enterprises, and even some schools require a doctorate degree[9]. At present, what China pays attention to in this respect is the education level, but there are no excessive requirements in terms of work experience, so that most of our teacher educators are from "School" to "school" lacks practical ability.

\subsection{Emphasizing the professional skills training of teacher educators}

In order to improve the educational skills of teacher educators, many foreign universities have their own training institutions and regularly train teacher educators. In Germany, teacher educator training activities have been written into the law, so that all vocational teacher educators are required to continue their education at the legislative level, and the application channels can be themselves or schools. The British government has very high requirements for the teaching quality of teacher educators. In 2001, it also established the College Teacher Educator Development Bureau. The main function of this institution is to provide further education and training management for teacher educators and actively help There are major problems in its professional development. In addition, this institution has established a professional network teaching mechanism[8]. Community colleges in the United States provide training funds for teacher educators each year to support their participation in training activities. In addition, they actively create opportunities for teacher educators to study abroad.

\subsection{Strengthening the internationalization of teacher educators}

If we divide the teacher educators accordingly from the regional perspective, it is mainly reflected in: domestic teachers, foreign teachers, domestic students, and international students. In a sense, foreign teachers and international students are the main manifestation of teacher educators' internationalization. They are also the result of the introduction of talents for education opening up. It is necessary to strengthen cooperation with foreign educational institutions and actively hire foreign Education experts carry out corresponding education activities so that teachers can feel the internationalized teaching environment, which is also the main manifestation of education reform and innovation[10].Teachers and student clients in the process of education and education for overseas study and further studies, this is the main embodiment of teacher educators in internationalization, can effectively expand the knowledge, learn advanced foreign knowledge and experience, and draw closer and developed countries in the teaching force Gap. On the whole, international student education is the most cost-effective foreign education market, and the proportion of international students is also a major manifestation of the internationalization of teacher education.

\section{CONCLUSION}

During the development of world economic integration, the world's economic and cultural exchanges are constantly being strengthened, and the opening up of education is also a very important task. Teacher education is the key to the 
country's talent training and laying the foundation for future talents. International comparative research on teacher educators, so as to train high-quality teacher educators, and use the power of talents to achieve global development. This has important practical significance for improving national exchanges and competitiveness in the world. Being able to improve a country's right to speak internationally has very important practical significance for scientific progress and social development.

\section{REFERENCES}

[1] Long Baoxin.On the Status and Trend of Professional Development of Foreign Teachers [J] .Researches in Modern Basic Education, 2016,23 (3): 25-35.

[2] Chen Chunjin. Teachers' Sense of Teaching Efficacy from the Perspective of International Comparison-An Empirical Study Based on TALIS Survey Data [J] .Global Education Outlook, 2017,46 (4): 11-22.

[3] Zhang Hualong. Teaching Practice of Professional Development of American Teachers: Case Analysis and Enlightenment [J]. Global Education Outlook.2009 (12): 66-70.

[4] Lu Naigui, Zhang Jiawei. Research on Teacher Development in Changing Times_- Interview with Professor $\mathrm{Lu}$ Naigui [J] .Journal of Suzhou University (Education Science Edition), 2018,6 (4): 77-84.

[5] Gao Shuguo.Analysis of the development stages and characteristics of Chinese education internationalization $[\mathrm{J}]$.China Higher Education Research, 2016 ( 12 ): 63- 67

[6] Xiang Xianming.A Global Perspective on Education Globalization: Dimensions, Impacts and Tension [J] .Journal of Beijing Normal University: Social Science Edition, 2008 (1): 5-13.

[7] Gao Yu.Reasonable Thinking on Deepening the Internationalization of Basic Education [J] .Researches in Educational Science, 2015 (5): 16-19.

[8] Zhao Shufeng.Exploration and Practice of Internationalization of Middle School Education_-Taking International Exchange Practice of Middle School Affiliated to Northeast Normal University as an Example [J] .Journal of Northeast Normal University (Philosophy and Social Sciences Edition), 2017 (2): 142-146.

[9] Guo han .Independence, innovation-the only way to explore the internationalization of education [J] .Future educators, 2015 (6): 23.

[10] Wang Xiaoning, Pu Xiaosong. Research on the Evaluation of Teachers' International Literacy in the Perspective of Internationalization of Basic Education [J]. Basic Education, 2017, 14 (5): 61-75. 